\title{
Rzymskie sympozjum na temat kan. 1095
}

Wydział Prawa Kanonicznego Papieskiego Uniwersytetu św. Krzyża w Rzymie zorganizował w dniach 26-27 kwietnia 2012 roku dwudniowe sympozjum naukowe na temat kan. 1095, w szczególności na temat rozeznania oceniającego oraz zdolności do podjęcia obowiązków małżeńskich ( $D i$ screzione di giudizio e capacità di assumere: la formulazione del canone 1095). Zamiarem organizatorów było przeprowadzenie interdyscyplinarnej refleksji naukowej na temat struktury oraz formowania się kan. $1095 \mathrm{w}$ przedmiocie małżeńskiej niezdolności konsensualnej. W szczególności w pierwszym dniu przedmiotem refleksji była analiza podstaw historycznych oraz doktrynalnych takiej niezdolności, natomiast w drugim dniu analiza obowiązującego tekstu prawnego wraz z jego aplikacją przez orzecznictwo Kościoła, w szczególności przez Rotę Rzymską. Po każdej sesji miała miejsce interesująca dyskusja z prelegentami.

Sesji porannej w pierwszym dniu sympozjum przewodniczył kard. Francesco Coccopalmerio - przewodniczący Papieskiej Rady ds. Tekstów Prawnych, który w swoim wprowadzeniu wskazał, że Papieska Rada, którą kieruje, jest praktycznie zainteresowana tematyką sympozjów kanonistycznych, co także tłumaczy jego obecność na tym międzynarodowym sympozjum dotyczącym materialnego kanonicznego prawa małżeńskiego, tym bardziej że odbyło się ono w Wiecznym Mieście. Okolicznościowe przemówienia wprowadzające do sympozjum wygłosili prorektor Papieskiego Uniwersytetu św. Krzyża w Rzymie ks. prof. P. Goyret (w miejsce nieobecnego rektora ks. prof. Luisa Romery), który podkreślił interdyscyplinarność tego sympozjum; dzie- 
kan Wydziału Prawa Kanonicznego - ks. prof. Luis Navarro, odnosząc się do rotalnego przemówienia papieża Benedykta XVI z 2011 roku, wskazał na trudności praktyczne w aplikacji kan. 1095, natomiast ks. prof. Miguel Ángel Ortiz - w imieniu komitetu organizacyjnego - zaprezentował strukturę sympozjum, które trzeba widzieć w relacji do rotalnych alokucji Jana Pawła II oraz Benedykta XVI z lat 1987, 1988 oraz 2009. Sukcesywnie zostały wygłoszone dwa referaty. Pierwszy, na temat zdolności konsensualnej do zawarcia małżeństwa z perspektywy antropologicznej, wygłosił ks. prof. Antonio Malo z Papieskiego Uniwersytetu św. Krzyża, natomiast drugi, na temat zdolności konsensualnej w optyce nauk psychologicznych oraz psychiatrycznych, wygłosił psychiatra dr Emilio Mordini - dyrektor Centrum Studiów Nauki, Społeczeństwa oraz Obywatelstwa w Rzymie.

Sesji popołudniowej, pod nieobecność bp. Juana Ignacio Arriety - sekretarza Papieskiej Rady ds. Tekstów Prawnych, przewodniczył ks. prof. Luis Navarro. Podczas tej sesji referaty wygłosili: ks. prof. Nicolàs Álvarez de las Asturias z Uniwersytetu św. Damazego w Madrycie - na temat zdolności konsensualnej do małżeństwa w historii prawa kanonicznego oraz ks. prof. Paolo Bianchi, oficjał Lombardzkiego Regionalnego Trybunału Kościelnego - na temat struktury kan. $1095 \mathrm{w}$ świetle ewolucji doktryny oraz orzecznictwa od lat siedemdziesiątych aż do dzisiaj.

Sesji porannej drugiego dnia sympozjum przewodniczył kard. Raymond Leo Burke - prefekt Najwyższego Trybunału Sygnatury Apostolskiej. Korespondujące referaty wygłosili ks. prof. Juan Ignacio Bañares z Uniwersytetu Navarra (Hiszpania) - na temat koncepcji rozeznania oceniającego, o którym w kan. 1095, nr 2 oraz bp Antoni Stankiewicz, dziekan Roty Rzymskiej - na temat koncepcji zdolności podjęcia istotnych obowiązków małżeńskich, o której w kan. 1095, nr 3.

Sesji popołudniowej przewodniczył ks. prof. Luis Navarro. Referaty wygłosili ks. prof. Carlos José Errázuriz Mackenn z Papieskiego Uniwersytetu św. Krzyża - na temat problematyki autonomii niezdolności do podjęcia istotnych obowiązków małżeńskich (kan. 1095, nr 3) oraz ks. prof. Héctor Franceschi, także z Papieskiego Uniwersytetu św. Krzyża - na temat kwestii niezdolności relatywnej w świetle struktury kan. 1095.

Sympozjum podsumował dziekan Navarro, który wskazał, że zarysowało ono różne propozycje oraz opinie, jednocześnie zapowiedział publikację materiałów z tego sympozjum jeszcze w tym roku kalendarzowym. 
Oceniając powyższą, dość intensywną, ale bardzo udaną oraz merytorycznie treściwą konferencję naukową w wiosennym, aczkolwiek już bardzo ciepłym Rzymie, należy podkreślić jej bardzo dynamiczny charakter, przede wszystkim w przedmiocie, ewentualnych zmian dotyczących kan. 1095.

W szczególności należałoby wskazać, że zwrócono uwagę na takie ogólne zagadnienia oraz problemy, jak:

- zagubienie w dzisiejszej kulturze, szczególnie tej zachodniej, naturalnego wymiaru małżeństwa. Antropolog prof. Malo stwierdził, że albo małżeństwo dla współczesnego człowieka jest niemożliwe, albo po prostu nie umiemy zrozumieć tej instytucji, na którą ludzka natura jest naturalnie ukierunkowana, w szczególności poprzez swoją komplementarność wyrażającą się poprzez męskość oraz kobiecość. Z kolei psychiatra Mordini wskazał, że przy współczesnej totalnej negacji instytucji małżeństwa należy, jako zjawisko negatywne, zauważyć równoczesny zanik przejścia z okresu niedojrzałego do dojrzałego w historii ludzkiego życia oraz stanowienia o sobie;

- prof. Bianchi podkreślił, że kan. 1095, nr 3 miał być pierwotnie autonomiczną normą kodeksową, sukcesywnie stał się trzecim przypadkiem kan. 1095, który stwarza tak ogromne trudności interpretacji procesowej; niemniej jednak jest to norma, która ma na celu także obronę instytucji małżeństwa. Wspomniany kanon trzeba widzieć także w odniesieniu do tradycji kanonistycznej (prof. Asturias ukazał matrimonium furiosi w Dekrecie Gracjana oraz w sukcesywnym rozwoju kanonicznego prawa małżeńskiego), jak również podkreślono, że istnieje ciągłość między kodyfikacją pio-benedyktyńską a janowo-pawłową.

- dziekan Stankiewicz wskazał, że kan. 1095, nr 3 zajmuje się nie sensem pozytywnym, ale negatywnym niezdolności konsensualnej. Podkreślił także, że należy mówić pozytywnie na temat zdolności konsensualnej, aby w ten sposób odkryć naturalny walor małżeństwa, o czym naucza także Benedykt XVI. Mówiąc na temat zdolności psychoseksualnej do małżeństwa, podkreślił, że aktualnie należy wskazywać także na jej aspekt dotyczący heteroseksualności. W dyskusji dziekan Roty Rzymskiej wskazał, że zniesienie dzisiaj 
(czy też zastąpienie inną norma) kan. 1095, zrodziłoby tylko problemy; normę tę należy interpretować poprzez poprawne stosowanie przez trybunały lokalne orzecznictwa rotalnego. Z kolei prof. Franceschi krytycznie wskazał, że orzecznictwo to praktycznie nie jest dostrzegalne właśnie w wyrokach trybunałów lokalnych. Wskazał on również, że mimo iż Rota Rzymska odrzuca jako autonomiczny tytuł nieważności zdolność tworzenia relacji interpersonalnych, czyli tzw. niezdolność relatywną, to jednak doktryna mówi na ten temat wyraźnie, a przede wszystkim aplikują ją trybunały lokalne;

- prof. Errázuriz wskazał, że konieczna jest właściwa „polityka” kanonistyczna, gdy idzie o ukazanie prawdy na temat małżeństwa, poprzez odwołanie się do tego, co jest rzeczywiście „sprawiedliwe”, czyli swoje rozważania przeprowadził w kontekście filozofii prawa oraz zaproponował własną, rozbudowaną, wersję kan. 1095, nr 2;

- podkreślono także, że $\mathrm{w}$ kanonicznym procesie małżeńskim sędzia musi odpowiedzieć na pytanie, „czy” jest małżeństwo, a nie „jak” było ono przeżywane. Stąd też nie należy dążyć do zbyt duchowego przedstawiania instytucji małżeństwa i dlatego jest potrzebna wizja małżeństwa oparta na kontrakcie (podkreślono w dyskusji, że nie można odchodzić od tego tradycyjnego rozumienia instytucji), z którego wynikają prawa oraz obowiązki, a te winny być doprecyzowane przez orzecznictwo Roty Rzymskiej, gdyż w doktrynie są różne opinie na temat takiego ewentualnego wykazu. Na końcu z satysfakcją należy stwierdzić, że stałym punktem odniesienia dla prelegentów oraz dyskutujących było nie tylko Magisterium Jana Pawła II i Benedykta XVI, ale także cytowanie licznych wyroków coram Stankiewicz. 